\title{
The impact of COVID-19 on family violence in immigrant communities in the United States
}

\author{
iD Abha Rai, Ph.D., MSW ${ }^{1}$, Susan F. Grossman, Ph.D., MA ${ }^{1}$ and ${ }^{\text {NDathan H. }}$ \\ Perkins, Ph.D., MSW ${ }^{1}$ \\ ${ }^{1}$ School of Social Work, Loyola University Chicago, Chicago, IL, USA
}

Received 14 October 2020

Accepted for publication 25 November 2020

Published 18 December 2020

\begin{abstract}
The COVID-19 pandemic has threatening implications for all individuals; and has been particularly unsettling for immigrants. Given their unique positionality in the U.S., the intersectional discussion about the impact of this pandemic on immigrants and issues of family violence is salient. The position of some groups of immigrant women is even more precarious due to the increased dependency on their spouse/partner for emotional, economic and immigration-related reasons. While immigrants have been on the frontlines as responders for COVID-19, there are limited policies that provide them with healthcare, employment guarantee, or benefits. Further, the immigration restrictions created by the U.S. Government have worsened the position of immigrants. All these stressors create unprecedented challenges for immigrants. Therefore, it is vital to delve into the family dynamics, unique challenges, and potential solutions that can provide support to immigrant families. This commentary highlights the atypical challenges of immigrants in relation to the pandemic and how these challenges may impact family violence. Through our discussion, we hope to encourage social work scholars, practitioners, and policy advocates, both in the U.S. and internationally to support and advocate for immigrants; especially, during the new normal under the COVID19 pandemic.
\end{abstract}

Keywords: COVID-19, immigrant communities, family violence, domestic violence, sibling violence

\section{Introduction}

The year 2020 witnessed unprecedented and troubling times with the outbreak of the COVID-19 virus. Given the rapid spread and deadly outcomes of the virus, on March 11, 2020, the World Health Organization (WHO) declared COVID-19 to be a pandemic (Cucinotta and Vanelli, 2020; Rochester Regional Health, 2020). Per the statistics provided by the Johns Hopkins University, as of late November a total of 13,393,166 COVID cases have been recorded in the United States (U.S.) alone. Of the reported infections, there have been 266,932 deaths making these numbers the highest globally (Johns Hopkins University, 2020, November 30), although COVID-19 has also impacted high numbers of individuals in regions across the world (Johns Hopkins University, 2020).

Owing to the lethal nature of COVID-19, its impact has been far-reaching on individuals and communities in the U.S. Yet this pandemic has had a particularly profound impact on diverse immigrant communities because of several factors that make them especially vulnerable both economically and physically. In this commentary, we highlight these factors and discuss how they, along with family dynamics and other key challenges that are unique to varying immigrant communities, may contribute to the incidence of family violence. We note that some of the factors we discuss play a part in all families, regardless of immigrant status. Further, we recognize that immigrants are not a single monolithic entity. There are differences between groups as well as within them, depending on factors such as acculturation. Therefore, whenever applicable and possible, we will identify the specific immigrant groups for which the contexts we discuss throughout this paper, may be relevant. While the focus of our paper is the U.S., the discussion and implications for immigrants may be partially relevant to other regions, such as the United Kingdom which houses a sizeable immigrant population as well. 


\section{Theoretical framework and foundation}

In this paper, we draw from theorists who highlight the multidimensional and intersecting aspects of identity including race, gender and class (Collins, 1990; Collins and Bilge, 2016; Crenshaw, 1991), as well as culture (Kapur, Zajicek and Gaber, 2017); and the way in which systems of power and individuals' relationships to these systems are experienced differentially, based upon these aspects of identity and the subsequent social groupings in which individuals are situated. Intersectionality theory thus posits that based on an individual's race, ethnicity, gender, class, and culture, their subsequent experiences, including their experience of violence (Cramer, Choi and Ross, 2017; Hattery and Smith, 2019) will differ. For instance, considering culture, race and gender, an intersectional framework suggests that an Asian immigrant woman may experience domestic abuse both similarly to and differently from a Caucasian non-immigrant woman based on factors such as the extent to which each woman's culture views women's status compared to men, the customary influence and involvement of in-laws, and identity factors such as immigration and employment status (Rai and Choi, 2018; Mahapatra and Rai, 2019).

Through this commentary, we utilize intersectionality as our guiding framework to first deconstruct distinct cultural nuances and barriers unique to immigrants and then to consider how these might impact family violence experiences among this group. We partner this framework with social work's person-in-environment perspective (Hare, 2004), to highlight both individual level and structural factors that may uniquely impact immigrants and their family violence experiences, specifically during COVID-19.

\subsection{Immigrant communities in the United States}

According to the Migration Policy Institute (Batalova, Blizzard and Bolter, 2020) there were more than 44.7 million immigrants in the U.S. in 2018. Immigrants, who comprise $13.7 \%$ of the U.S. population, have significantly grown in numbers over the past few years (Batalova, et al., 2020). Most immigrants remain legally in the U.S.; however, estimates suggest that there are about 10.5 million unauthorized immigrants (Radford, 2019). Immigrants from South and East Asia account for $27 \%$ of all immigrants, which is close to the proportion of immigrants from Mexico (25\%). While these two regions account for the highest proportion of immigrants, other regions make up smaller percentages such as those from Europe/Canada (13\%), the Caribbean (10\%), Central America (8\%), South America (7\%), the Middle East (4\%) and SubSaharan Africa (4\%). Immigrants constituted as high as $17 \%$ of the American labor force in 2017 and are projected to drive the workforce population by 2035 (Radford, 2019).

As high as 1 million immigrants arrive in the U.S. each year with those from India $(126,000)$ being the highest in 2017, followed by Mexico (124,000), China (121,000), and Cuba (41,000). Asian immigrants comprise the greatest number of immigrants since 2010 when trends by race and ethnicity are examined. By 2055, Asian immigrants are projected to become the largest immigrant group in the U.S. (Radford, 2019).

The diverse groups of immigrants in the U.S. come from distinctive cultures, family values and lifestyles making their experience different from native born Americans residing in the U.S. Further, the collectivist family values of many immigrant communities, especially those from Asian countries, Mexico and Cuba, combined with immigration and acculturation challenges, may create conditions which make these communities particularly vulnerable to family violence (Balgamwalla, 2013; 2014; Goel, 2005; Voolma, 2018). Adding in the stressful conditions unique to immigrants related to the COVID-19 pandemic, coupled with some community norms such as support for patriarchal beliefs, keeping family matters private and the need for women to safeguard family interests before their own, the risk of family violence may be even higher among these communities at this time (Goel, 2005; Sabri, Simonet and Campbell, 2018).

\subsection{Meaning of family violence in immigrant families}

Generally speaking, family violence in immigrant communities is a complicated phenomenon. Family violence can include physical, emotional, verbal, and sexual abuse and:

...is a subtype of interpersonal violence that includes violence among intimate partners (including dating violence), family members, and people known by the family who are often viewed as friends or extended family members (whether or not they are actual family members by birth, marriage, or adoption) (Lawson, 2013, p. 3).

Interestingly, within the context of immigrant families, family violence has been used synonymously with domestic violence. While many immigrant cultures define marriage to include heterosexual relationships, the term domestic violence includes physical, emotional, verbal, financial, sexual and immigration-related abuse perpetrated on an individual either by their spouse or spouse's extended kin (Futures Without Violence, n.d.; Rai, 2020a). As high as $21-40 \%$ of immigrants have experienced domestic violence in their lifetime, but, community-based experts point to much higher prevalence rates (Murugan, 2018; Soglin et al., 2020; Yoshioka, Gilbert, El-Bassel, and Baig-Amin, 2003). Data from the Bureau of 
Justice Statistics make clear that while both men and women can be victims of domestic violence, women are still the majority of victims (U.S. Department of Justice, 2015), and while the Bureau does not provide data by immigration status, data specifically on immigrant communities from other sources reflect this same trend of female victimization rates exceeding those of males (Ahn, 2002; Soglin et al., 2020; Yoshihama et al., 2011; Rai, 2020a).

The victimization of women also makes their children vulnerable to child abuse and neglect (Bragg, 2003), increasing children's experiences of depression, anxiety and, fear, thus impacting their behavior (Cohen, Brown and Smailes, 2001; Price, 2019; Phelps and Sperry, 2020). These imbalances in children's behavior may lead to increased chances of sibling violence among those with siblings. Currently, research on sibling violence in immigrant families is scant. U.S. national estimates of physical sibling violence are around $30 \%$ for children and adolescents (Finkelhor et al., 2015), however, estimates of sibling violence within immigrant families in the U.S. remain unknown. While no known research specifically examining sibling violence in immigrant families exists, Rapoza et al. (2010) conducted a study examining perspectives of sibling violence in an ethnically diverse (Latin/Hispanic, Asian Pacific, South Asian, Native American, African American, and European) sample of U.S. citizens. All participants noted that sibling abuse occurs in families with the most common types being physical and psychological. Though this sample did not include immigrants, it is likely that the variation of ethnic groups included in the study may provide support to the potential for sibling violence to occur in immigrant families, too.

\subsection{Factors impacting family violence in immigrant communities}

Owing to some cultural attributes like the dismissal of violence to protect family honor, gender disparity, and patriarchy, some immigrant families are more prone to experiencing family violence as compared to Western communities (Barnett, Miller-Perrin and Perrin, 2005; Viveiros and Bonomi, 2020; Yoshihama et al., 2011). For example, in many South Asian immigrant cultures, daughters are taught to be subservient to their fathers, brothers, and uncles before their marriage and to ultimately surrender to their husband after marriage. Sons, on the other hand, are provided with more opportunities all through their childhood (Goel, 2005; Rai and Choi, 2018). This imbalance in power translates into a difference in gender expectations and roles (Dasgupta, 2007). The "inferior" status of women forces them to stay dependent on their male partners after marriage.
Further, some immigrant cultures, particularly certain Asian and Latin/Hispanic communities, may embrace collectivist family values (Shirwadkar, 2004) that can force women to safeguard the interests of the family before their own and to become silent victims of abuse, when violence is directed toward them.

Along with cultural influences, there exist a multitude of structural barriers that immigrant women in the U.S. experience. A high proportion of those women are currently on a dependent visa type which means their legal status is tied to that of their husband or primary visa holder (Balgamwalla, 2013; 2014; Voolma, 2018). Given this dependency, women are unable to maintain an independent bank account, seek a driver's license, or hold independent residency in the U.S. (Balgamwalla, 2013; 2014; USCIS, 2017). Their dependent visa status, in some cases, also limits the employment seeking capability of some immigrant women as well as their ability to independently access the healthcare system (USCIS, 2017; Islas, 2020; Tahirih Justice Center, 2020). As a result, immigrant women are more prone to immigration-related abuse such as control over their passports and/or green cards by their spouse or spouse's family. Such women may also be reliant on their spouse for their daily expenses, childcare, and insurance support. Ultimately, this lack of agency may force women to continue staying in abusive relationships without seeking help (Ahmad et al., 2009; Voolma, 2018). Further, the current anti-immigration sentiment in the U.S. discourages immigrant women from contacting agencies or the criminal justice system even in cases of extremity (Laitner, 2020). They may fear having their partner/spouse deported or being separated from their children should they seek such contact (Yoshihama et al., 2011; Rai, 2020a). Therefore, reporting abuse is not an option available for many immigrant women.

The next sections of this paper look specifically at the impact of COVID-19 on the immigrant community and then, at the intersection of immigrant status, COVID-19 and family violence. We conclude with recommendations for social work researchers, practitioners and policymakers in the hopes of addressing some of the problems highlighted here.

\section{Immigrant communities and COVID-19}

According to the Migration Policy Institute (Gelatt, 2020), foreign-born individuals are over-represented in the job sectors that were affected most immediately by shelter-inplace (i.e. to limit the spread of COVID-19, many states implemented shelter-in-place or stay at home orders since the pandemic began. According to this order, residents are required to stay at home except for going out for emergencies and essentials like doctor's appointment, groceries or to 
purchase medical supplies [Gajanan, 2020]), policies including restaurants, hotels, office cleaning services, and inhome health care. Depending on their migration status, immigrants in these sectors may not be eligible for unemployment benefits or many other safety-net programs once they lose their jobs (Gelatt, 2020). Further, undocumented workers have been altogether left out of federal relief programs specifically related to COVID-19 (Chishti and Bolter 2020; Narea, 2020a; Jordan, 2020) although more recently, some states have begun to take action in support of their undocumented immigrant populations by providing monetary benefits (Jordan, 2020).

Immigrants also comprise large proportions of essential workers in industries that remain open during the crisis (Chishti and Bolter, 2020; Chishti and Pierce, 2020; Gelatt, 2020). Not only are they among those who work in the grocery stores and pharmacies that have remained open, but they are also among those most critical to the pandemic response. For example, they comprise $29 \%$ of physicians, $22 \%$ of nursing assistants, $29 \%$ of housekeepers, and $24 \%$ of janitors, and building cleaners in the healthcare industry (Galett, 2020). While their representation in essential industries means they must work during the pandemic, immigrants are also less likely to have health insurance (Narea, 2020a; KFF.Org, 2020). Consequently, if they become ill, they may be less likely to get treatment.

Undocumented individuals may also fear getting tested, even though testing in the U.S. is now free, because of concerns about exposing their migration status or losing employment. Other conditions related to recent and current policies towards undocumented immigrants, including the use of detention centers that group immigrants together, also exacerbate the health risks for certain immigrant groups (Lee et al., 2020) although the numbers of detainees are reportedly declining (U.S. Immigration and Customs Enforcement, 2020). Chishti and Bolter (2020), also suggest that living conditions more typical of immigrant communities than those of White, native born citizens, including household overcrowding, make them more vulnerable to the virus. Along with these structural barriers, some groups, such as Asian Americans and Asian immigrants, specifically have been scapegoated for spreading the virus in several recorded incidents of xenophobia (Chishti and Bolter, 2020). This incrimination is bound to increase post remarks by President Trump calling COVID-19 the 'Chinese virus,' and 'kung flu' at his recent Tulsa rally and Presidential debate, among other occasions (Griffiths, 2020; Moreno, 2020).

\subsection{The impact of COVID-19 on family violence in immigrant communities}

Circumstances differ from family to family, but the COVID-19 crisis has serious implications for domestic violence in families, especially for families with histories of domestic violence. Social media has been flooded with the news of domestic violence cases surging under the pandemic (Davis, Gilbar and Padilla-Medina, 2020; Fielding, 2020; Tolan, 2020; Mittal and Singh, 2020). Further, responses to the pandemic, including increased sales of guns and body armor in some areas also mean increased risk of lethality when violence does erupt (Snyder, 2020). This could be harmful both for immigrant and non-immigrant victims of abuse.

In many immigrant families, the abuser who as noted is usually the male partner, may control access to cellphones, laptops, and in several cases, the social interaction of abused women. Due to the limited social interaction with friends and family, immigrant women have fewer options for making safety plans to escape their abuser and seeking respite. Factors such as the urge to upkeep family honor as well as fear of seeking help from formal sources or the criminal justice system, may mean that immigrant women are more likely to seek help from informal resources such as friends or family members when domestic violence occurs (Ahmad et al., 2009; Mahapatra and Rai, 2019). However, stay at home orders and social distancing during the COVID-19 pandemic have meant that many women have been unable to reach out to friends and family for support, including support around violence (WHO, 2020).

The shutdown has also affected both immigrant and nonimmigrant survivors' ability to access essential services like ongoing support groups or legal and court assistance. This is because agencies are closed or services are provided only online or by phone and victims cannot access technology or speak on the phone safely in their homes (Berger, 2020; Gupta and Stahl, 2020; Selvaratnam, 2020; Southall, 2020; United Nations Women, 2020b). Although many domestic violence shelters are set up to accommodate people in more isolated living quarters (Lang, 2020), some may be forced to limit the number of available beds because of social distancing demands (Gupta and Stahl, 2020). Further, survivors may resist going to shelters or staying with other family members or friends because they fear exposure to the virus in new settings (Southall, 2020). Some immigrant survivors may also be hesitant about seeking external help due to the taboo attached to conversations about domestic violence and divorce in immigrant cultures, more specifically some Asian and Latin/Hispanic groups (Dasgupta, 2007; Goel, 2005). 
Serrata and Alvarado (2019) while discussing the impact of natural disasters on domestic violence, assert that the stresses associated with a disaster lead to higher rates of domestic violence and child abuse. While not a natural disaster, it is clear that similar stressors, including joblessness, strained finances and social isolation exist under the current pandemic. These stressors can affect all communities; however, their impacts are somewhat unique for immigrants. As noted previously, many immigrants were employed in those sectors of the economy that were affected immediately by the shutdown and many remain unemployed with little access to benefits. For skilled immigrant workers, things are a bit more complex but no less difficult. These workers come to the U.S. under the H-1B visa program and are sponsored by their employers. When someone loses their job, these visas are canceled, and the employee must find a new job with a company that is willing to take on sponsorship. The pandemic makes this even more challenging.

Recent executive orders signed by President Trump have further restricted immigration by suspending green cards and limiting the number of $\mathrm{H}-1$ visas for immigrants (Garcini et al., 2020; Kolakowski, 2020). These stipulations have been focused on creating more jobs for Americans to stabilize the economy, but they put immigrants in an even more precarious position than earlier, due to limited sponsorship options (Garcini, et al., 2020; Kolakowski, 2020). Undoubtedly, the stress of coping with a pandemic and the fear of losing or having already lost their sole means of livelihood, is troubling for immigrant communities at large. These pressures could lead to new and increased instances of domestic violence in impacted families.

Another result of the pandemic and shelter-in-place orders is that due to the closure of schools, and daycare and activity centers, many parents now have childcare and homeschooling obligations. What is unique for families in several immigrant cultures, is that among those with rigid gender-role expectations (for example some Cuban, Mexican or South/East Asian communities), mothers, who are often the ones with caregiving responsibilities, must now also put in long hours at work and at home caring for children. While extended families among many immigrant groups provide additional help and support with childcare, concerns about spreading COVID-19 has likely limited their involvement at this time, potentially placing greater care-giving burdens on mothers. COVID-19 related travel bans have additionally restricted help by preventing families who are overseas from coming to the U.S., although this is now slowly starting to change (Chishti and Pierce, 2020; U.S. Embassy and Consulates in India, 2020). Most critically, failure in caring for children and meeting their specified gender ascribed roles may also lead to spousal frustration, creating new instances of domestic violence (Goel, 2005; Yoshioka et al., 2003).

This same pattern of rigid gender-role expectations in some immigrant communities combined with the lack of extended family involvement thereby leading to decreased parental supervision may also result in an increased risk of sibling violence and conflict among siblings (Caffaro and Con-Caffaro,1998; Wiehe, 1997; Winters, 2019) particularly if the mother is the only caretaker and she cannot supervise her children. If children go unsupervised for longer time periods and are left to manage their sibling relationships on their own, they may be confronted with challenging interpersonal situations that can lead to violence, especially if knowledge of how to handle conflict appropriately is missing. Clearly, parental neglect of children can have long-term detrimental emotional and behavioral effects (Norman et al., 2012), and the risk of child neglect may be higher for those immigrant families where the burden of caregiving is predominantly on mothers. Overall, this pandemic has created ubiquitous challenges for immigrant communities.

\section{Implications for social work}

\subsection{Research implications}

Immigrants are facing atypical challenges in these unprecedented times. It is imperative to provide support to adults as well as children belonging to immigrant communities. Social work researchers and scholars in the U.S. and other foreign countries with a considerably large number of immigrants such as Canada, the United Kingdom and Australia are encouraged to engage in research with immigrant communities so that new empirical evidence about the unique circumstances faced by immigrants as well as their specific needs can be generated. However, research with immigrant groups, in general across countries and contexts, has unique barriers that are compounded by the challenges of specifically conducting research on domestic violence. Adding the issue of COVID-19 to the mix makes such research particularly daunting, and yet, as UN Women and the World Health Organization point out, data on violence against women during the pandemic is essential for understanding how and why pandemics may lead to an increase in violence as well as the services and supports that may be most important (Sexual Violence Research Initiative, 2020; United Nations Women, 2020a). We note the following as implications and recommendations for ongoing research in this area.

First, it is essential to distinguish between immigrant groups allowing disaggregation. Immigrants are not one monolithic entity and violence as well as its impact may look 
different for different populations. Research instruments and data collection methods need to be sensitive to these differences as well as to variations in acculturation, generational position and, immigration status. For example, the Conflict Tactics Scale (Straus et al., 1996) which is a widely used measure to capture domestic violence experiences, may not be relevant for immigrant communities as it does not capture the unique cultural nuances that can perpetuate violence among immigrants such as immigrationrelated abuse and abuse through in-laws (Goel, 2005; Voolma, 2018; Rai and Choi, 2018). New instruments that capture these tactics of family and domestic violence need to be developed and tested with immigrants. Further, samples in future research need to be large enough to allow for representation and analyses of sub-groups within specific immigrant groups and across groups. For example, Agha and Rai (2020) noted that disaggregation is essential to explicate the unique nuances concerning specific communities, so scholars and practitioners can develop innovative ways of intervening with them.

Second, given that we do not necessarily have access to violence survivors while quarantine and social distancing measures are in place, we need to be creative in thinking about sources of data and informants that can provide useful information. Clearly, we do not want to collect data in spaces where we cannot be certain that survivors are safe and that they have privacy (United Nations Women, 2020a). Alternatives might be to collect data about individuals' perceptions of family violence, their challenges and resources that have been found to be helpful through social media such as Twitter, Facebook and Instagram or through mobile apps, a strategy used by researchers in the past (myPlan, 2019). Additionally, the UN Women and the World Health Organization, suggests sources such as key informant interviews with service providers and frontline workers as well as utilization of service-based data, case reports, media reports, and when possible, participatory data collection approaches (United Nations Women, 2020a). The latter may be especially helpful when working in immigrant communities. Immigrant survivors who participate in interviews may feel more comfortable talking with interviewers who are survivors and from similar ethnic communities. Language barriers may necessitate this arrangement. Indeed, including survivors as participants in crafting interview questions via community-engaged research and making design decisions, may ensure that the research is culturally appropriate and helps with recruitment and retention issues.

It is essential that we make sure the data we collect are secure and that survivors' identities as well as their locations are kept confidential. Modifications to data collection methods that have been necessary because of COVID-19, such as use of computer technologies mean that we need to be sure our computers have data protection systems and that any electronic communications we have with potential participants do not leave a trail (United Nations Women, 2020a). Finally, we need to consider what the data we collect may tell us. There are varying reports about whether calls to hotlines are up or down (Selveratnam, 2020; Southall 2020; United Nations Women, 2020b). However, a decline in calls may not mean that violence has decreased. It may more accurately reflect that survivors do not have the freedom to access telephones in order to make calls (United Nations Women, 2020a). In other words, we need to consider the context and strive to learn as much as possible before concluding about what different patterns of behavior and service utilization may mean. These research implications and strategies can be relevant for researchers both in the U.S. and internationally who are engaging with immigrant communities.

\subsection{Practice implications}

Community-based organizations (CBOs) and service providers, both in the U.S. and internationally, that are engaged in work with immigrants and family violence issues are encouraged to partner with researchers to ensure that novel ways are being used to provide services to immigrant communities; such as through secure apps, online self-care classes, and using innovative code words to flag domestic violence cases (Futures without violence, n.d.; Kottasova, 2020). Along with domestic violence victims, it is essential to make online classes and activities more accessible for children in particular (Clement, 2020). These remote online activities can help alleviate the burden of "parenting" from mothers in certain immigrant families. Activities of this nature may also provide more opportunities for children to become independent and self-reliant, which may be absent in some immigrant cultures.

Social workers and advocates from CBOs are also encouraged to liaise and propose new and safe ways to checkin with immigrant families. These check-in sessions can be used to facilitate remote meditation classes and self-care activities to help victims who may not be able to actively reach out for help, to manage their stress (Futures without violence, n.d.; Rai, 2020b). Such sessions can also help children learn how to address tense situations and provide parents and children resources to address sibling violence and prevent it from happening (Perkins and Shadik, 2018). It is pressing for community partners to take proactive measures to support immigrant families because the social distancing and home- 
schooling mandates may continue for a while across the world. While these strategies are being discussed in the context of immigrants in the U.S., they can be used with immigrants internationally as well, based on the extent of engagement of community organizations with immigrants and family violence issues.

\subsection{Policy implications}

Ultimately, the excruciating circumstances created by COVID-19 on immigrants' lives call for an urgent need for policy amendments related to immigrants. The antiimmigration climate perpetrated by President Trump through his latest immigration ban worsens the position of immigrants (Garcini et al., 2020; Yang and Bloomberg, 2020). A significant proportion of immigrants have been impacted by the latest executive order issued on June 24, 2020 and have been separated from their families overseas (Kolakowski, 2020). Several of those who remain in the U.S. without their families and/or spouses may now be struggling to maintain their legal status and be forced to go to work even when sick. This stipulation challenges the fundamental human rights available to immigrants.

Also, the Violence Against Women Act (VAWA) needs to be made more accessible to victims. The onus of demonstrating victimization is on the petitioner, which can discourage victims from self-petitioning (USCIS, 2016). The increased complexities of gathering all documentation pertaining to submitting a VAWA petition may be impossible without a lawyer, eliminating thousands of eligible individuals from taking advantage of this legislation. Community organizations serving immigrant subgroups must therefore provide immigrants with more targeted information and support related to submitting self-petitions under VAWA or relevant acts in other countries. Some immigrants may even face language barriers (Balgamwalla, 2014; Goel, 2005), so social workers can help prepare these documents on behalf of petitioning clients; and possibly also serve as liaisons during interaction with attorneys.

Finally, based on the current stipulations of the VAWA, there are only up to $10,000 \mathrm{U}$-visas each year available for all victims who have experienced violence, as compared to the 44 million and increasing immigrants in the U.S. (American Migration Council, 2019; Batalova et al., 2020). Advocacy efforts focused on increasing the number of such visas are essential and provide a clear role for social workers who can collaborate with state and central federal bodies to petition for changes around this provision. There are similar laws in other countries which need to be examined as well. Social workers in other countries can also actively engage with their legislatures to petition for necessary policy changes.

Given the aforementioned stress COVID-19 can have for families, parents within immigrant families also need to be made aware of policies within the U.S. which aim to protect children. The Child Abuse and Treatment Act of 1974 (CAPTA, 1974) provides funding to States within the U.S. for the "prevention, assessment, investigation, prosecution, and treatment activities related to abused and neglected children" (Harfeld and Marlowe, 2017, p. 117). Exceptions to child abuse and neglect laws can exist due to religious beliefs and practices of parents regarding medical care (Committee on Bioethics, 1997), with 34 states and the District of Columbia having these exceptions (Sandstrom, 2016). However, this does not apply to violence directed toward children. Furthermore, in the case of physical and emotional sibling violence, while explicit policies do not exist to address this form of violence (Perkins and Grossman, 2020; Perkins, Cole and O'Connor, 2017), it has been suggested that failure to protect laws should consider including holding parents accountable when violence directed from one sibling to another occurs (Perkins and Barry, 2020). Parents from immigrant families may not be aware of such policies or mechanisms holding them liable for violence that occurs toward their children; thereby highlighting the need for family psychoeducation of existing policies and laws designed to protect children. Social workers working with immigrant families can also develop awareness education programs for parents; relating to sibling violence, child abuse and neglect so that they are more aware of the provisions and legal rights of their children. Further, older teenage children who are in a position to understand these policies and laws can also be included in separate educational programs designed specifically for them. It is imperative for children along with parents to be aware of the meaning and scope of sibling violence as well as child abuse and neglect.

In tandem with policies that address survivors of violence and support their needs, policies that target immigrants' economic conditions are also essential as preventive efforts. This includes broadening income support to undocumented immigrants through federal policies replicating what is occurring in some states presently (Jordan, 2020), particularly related to unemployment insurance. The HEROES Act mandated that all immigrants with or without social security numbers would be eligible to receive stimulus payments (Narea, 2020b). Policy advocates and lobbyists must ensure that these provisions are actually reaching immigrants. Joint interventions where social workers and policy lobbyists can partner, may be critical in making these federal stipulations accessible to immigrant groups. 


\section{Conclusion}

Through this paper, it is our hope to draw attention to the unique and oftentimes excruciating circumstances faced by immigrants amidst the COVID-19 pandemic in the U.S. Despite assuming important positions in American society, making contributions to the American economy, and being on the frontlines, immigrant families overall and particularly immigrant survivors of violence have been severely disadvantaged due to the COVID-19 virus. Despite this paper being situated within the U.S., the implications as well as the vital role of social workers in advancing the well-being and ensuring the availability of resources to immigrants has global connotations.

As we continue to remain in this pandemic, more access to resources, culturally responsive interventions and policy-level changes must be implemented for immigrant communities. Furthermore, researchers and scholars are encouraged to continue examining the unique challenges and needs of immigrant families to better inform individual, family, and community practice as well as policy. These collective efforts will hopefully lead to a reduction in domestic and family violence among immigrant communities. Our discussion has implications for other foreign countries as well that house a predominately high number of immigrant communities. It is imperative that social work professionals as well as those from other helping professions such as psychologists, and counselors pay special attention to immigrant communities and address their needs. Unique family violence interventions and support services need to be developed to adequately aid immigrant families during this global pandemic.

\section{Acknowledgements}

We would like to thank Erica Fada, Graduate Assistant and student in the dual MSW/MA Program and Women's Studies program at Loyola University, Chicago for her help in preparing the final manuscript.

\section{References}

Agha, E. and Rai, A. (2020) 'Notes from the field: Culturally adapted research methods for South Asian participants', Professional Development Journal, 23(1), pp. 27-31.

Ahmad, F., Driver, N., McNally, M.J. and Stewart, D.E. (2009) 'Why doesn't she seek help for partner abuse? An exploratory study with South Asian immigrant women', Social Science and Medicine, 69(4), pp. 613-622.
American Migration Council (2019) Violence against women act (VAWA) provided protections for immigrant women and victims of crime. Available at: https://www.americanimmigrationcouncil.org/research/vio lence-against-women-act-vawa-immigration (Accessed: 7 October 2020).

Ahn, B. (2002) The perceptions of and attitudes toward partner abuse among first-generation Korean-Americans: Their relationships to the incidence of partner abuse (Unpublished doctoral dissertation). Louisiana State University and Agricultural and Mechanical College. Available https://digitalcommons.lsu.edu/gradschool_dissertations/2 $167 /$ (Accessed: 5 October 2020).

Balgamwalla, S. (2013) A woman's place: Dependent spouse visa holders and the legacy of coverture. Available at: https://law.ubalt.edu/centers/caf/pdf/Sabrina\%20Balgamw alla.pdf (Accessed: 7 October 2020).

Balgamwalla, S. (2014) 'Bride and prejudice: How US immigration law discriminates against spousal visa holders', Berkeley Journal of Gender, Law and Justice, 29(1), pp. 24-71.

Barnett, O., Miller-Perrin, C.L. and Perrin, R.D. (2005) Family violence across the lifespan: An introduction. Thousand Oaks, CA: Sage Publications, Inc.

Batalova, J., Blizzard, B. and Bolter, J. (2020). Frequently requested statistics on immigrants and immigration in the United States. Available at: https://www.migrationpolicy.org/article/frequentlyrequested-statistics-immigrants-and-immigrationunitedstates\#Immigrants\%20Now\%20and\%20Historically (Accessed: 7 October 2020).

Berger, M. (2020) Measures to control the spread of coronavirus are a nightmare for victims of domestic violence. Advocates are demanding governments step up. Washington Post. Available at: https://www.washingtonpost.com/world/2020/04/01/meas ures-control-spread- coronavirus-are-nightmarevictims-domestic-violence-advocates-are-demanding-thatgovernments-step-up/ (Accessed: 7 October 2020).

Bragg, H.L. (2003) Child protection in families experiencing domestic violence. Available at: https://www.childwelfare.gov/pubPDFs/domesticviolence. pdf (Accessed: 6 October 2020).

Caffaro, J.V. and Conn-Caffaro, A. (1998) Sibling abuse trauma: Assessment and intervention strategies for children, families, and adults. Binghamton, NY: Haworth Press. 
Child Abuse Prevention and Treatment Act (CAPTA) of 1974, 42 USC $\$ \S 5101$ (1974).

Chishti, M. and Bolter, J. (2020) Migration Policy Institute. Vulnerable to COVID-19 and in frontline jobs, immigrants are mostly shut out of U.S. relief. Available at: https://www.migrationpolicy.org/article/covid19immigrants-shut-out-federal-relief (Accessed: 7 October 2020).

Chishti, M. and Pierce, S. (2020) Migration Policy Institute. Crisis within a crisis: immigration in the United States in a time of COVID-19. Available at: https://www.migrationpolicy.org/article/crisis-withincrisis-immigration-time-covid-19 (Accessed: 6 October 2020).

Clement, O. (2020) '25 theatre-related online resources for kids and families to get you through COVID-19', Playbill. Available at: https://www.playbill.com/article/21-theatrerelated-online- resources-for-kids-and-families-to-get-youthrough-covid-19 (Accessed: 5 October 2020).

Cohen, P., Brown, J. and Smailes, E. (2001) 'Child abuse and neglect and the development of mental disorders in the general population', Development and Psychopathology, 13(4), pp. 981-999.

Collins, P.H. (1990) Black feminist thought: Knowledge, consciousness, and the politics of empowerment. Boston, MA: UnwinHyman.

Collins, P.H. and Bilge, S. (2016) Intersectionality. Cambridge: Policy Press.

Committee on Bioethics, American Academy of Pediatrics. (1997) 'Religious objections to medical care', Pediatrics, 99(2), pp. 279-281.

Cramer E.P., Choi Y.J. and Ross A.I. (2017) 'Race, culture, and abuse of persons with disabilities' in Johnson A., Nelson J. and Lund E. (eds) Religion, Disability, and Interpersonal Violence, Cham, Switzerland: Springer, pp. 89-110.

Crenshaw, K. (1991) 'Mapping the margins: Intersectionality, identity politics, and violence against women of color', Stanford Law Review, 43, pp. 1241-1299.

Cucinotta, D. and Vanelli, M. (2020) 'WHO declares COVID19 a pandemic', Acta bio-medica: Atenei Parmensis, 91(1), pp. 157-160.

Dasgupta, S.D. (2007) Body evidence: Intimate violence against south Asian women in America. New York: Rutgers University Press.

Davis, M., Gilbar, O. and Padilla-Medina, D. (2020) 'Intimate partner violence victimization and perpetration among
U.S. adults during COVID-19: a brief report', BMJ Yale, pp. 1-14. Doi: https://doi.org/10.1101/2020.06.08.20125914

Fielding, S. (2020) 'In quarantine with an abuser: surge in domestic violence reports linked to coronavirus.' The Guardian. Available at: https://www.theguardian.com/usnews/2020/apr/03/coronavirus-quarantine-abusedomestic-violence (Accessed: 6 October 2020).

Finkelhor, D., Turner, H.A., Shattuck, A. and Hamby, S.L. (2015) 'Prevalence of childhood exposure to violence, crime, and abuse: Results from the national survey of children's exposure to violence', JAMA Pediatrics, 169(8), pp. 746-754.

Futures without violence (n.d.) Forms of domestic violence that women experience: immigrant women. Available at: https://www.futureswithoutviolence.org/wpcontent/uploads/Power-Control-Wheel-Eng-7-18.pdf (Accessed: 5 October 2020).

Gajanan, M. (2020) 'What does 'shelter-in-place' mean? Here's what life is like under the mandate.' Time. https://time.com/5806477/what-is-shelter-in-place/ (Accessed: 22 November 2020).

Garcini, L.M., Domenech Rodríguez, M.M., Mercado, A. and Paris, M. (2020, in press) 'A tale of two crises: The compounded effect of COVID-19 and anti-immigration policy in the United States', Psychological trauma: Theory, Research, Practice, and Policy. Advance online publication.

Gelatt, J. (2020) Migration Policy Institute. Immigrant workers: Vital to the U.S. COVID-19 response, disproportionately vulnerable, fact sheet. Available at: https://www.migrationpolicy.org/research/immigrantworkers-us-covid-19-response (Accessed: 22 November 2020).

Goel R. (2005) 'Sita's Trousseau: restorative justice, domestic violence, and South Asian culture', Violence Against Women, 11(5), pp. 639-665.

Griffiths, J. (2020) 'Trump has repeatedly blamed China for a virus that now threatens his health. This will make Beijing nervous.' $\quad C N N$. Available at: https://www.cnn.com/2020/10/02/asia/trump-chinacoronavirus-intl-hnk/index.html (Accessed: 5 October 2020).

Gupta, A.H. and Stahl, A. (2020) 'For abused women, a pandemic lockdown holds dangers of its own.' New York Times. Available at: https://www.nytimes.com/2020/03/24/us/coronavirus- 
lockdown-domestic- violence.html (Accessed: 5 October 2020).

Hare, I. (2004) 'Defining social work for the $21^{\text {st }}$ century. The International federation of Social Worker's revised definition of social work', International Social Work, 47 (3), pp. 407-424.

Harfeld, A. and Marlowe, K. (2017) 'Making America's children safe again: Advocating for CAPTA reform and beyond', Juvenile and Family Court Journal, 68(1), pp. 115-128.

Hattery, A.J. and Smith, E. (2019) Gender, power and violence: Responding to sexual and intimate partner violence in society today. Lanham: Rowman and Littlefield.

Islas, G. (2020) 'The COVID-19 pandemic has a new victim: undocumented women in abusive relationships.' The Fresno Bee. Available at: https://www.fresnobee.com/opinion/readersopinion/article241988931.html (Accessed: 6 October 2020).

Johns Hopkins University and Medicine Coronavirus Resource Center (2020) Available at: https://coronavirus.jhu.edu/us-map (Accessed: 5 October 2020).

Jordan, M. (2020) 'California Offers $\$ 500$ in Covid-10 Aid to Undocumented Immigrants.' The New York Times. Available at: https://www.nytimes.com/2020/05/18/us/coronavirusundocumented-california.html? searchResultPosition $=2$ (Accessed: 6 October 2020).

Kapur, S., Zajicek, A.M. and Gaber, J. (2017). 'Nonprofit organizations serving domestic violence survivors: Addressing intersectional needs of Asian Indians', Affilia: Journal of Women and Social Work, 32(1) pp. 50-66.

KFF.org. (2020) 'Health coverage of immigrants.' Available at: $\quad$ https://www.kff.org/disparities-policy/factsheet/health-coverage-of-immigrants/ (Accessed: 6 October 2020).

Kolakowski, N. (2020) 'Apple, Google Twitter react to Trump H1-B visa ban.' Dice. Available at: https://insights.dice.com/2020/06/25/apple-google-twitterreact-trump-h-1b-visaban/?ads kw=H1\%20B\%20Visa\%20Ban (Accessed: 6 October 2020).

Kottasova, I. (2020) 'Women are using code words at pharmacies to escape domestic violence during lockdown.' $\quad C N N$. Available at: https://www.cnn.com/2020/04/02/europe/domesticviolence-coronavirus-lockdown-intl/index.html

(Accessed: 7 October 2020).

Laitner, M. (2020) 'Not always safer at home: COVID-19 and domestic violence.' Society for Women's Health Research. Available at: https://swhr.org/not-always-safer-at-homecovid-19-and-domestic-violence/ (Accessed: 5 October 2020).

Lang, M.L. (2020) 'Domestic violence will increase during coronavirus quarantines and stay-at-home orders, experts warn.' Washington Post. Available at: https://www.washingtonpost.com/local/domesticviolence-will-increase-during-coronavirus-quarantinesand-stay-at-home-orders-expertswarn/2020/03/26/04e63d6a-6d37-11ea-b148e4ce3fbd85b5_story.html (Accessed: 4 October 2020).

Lawson, D.M. (2013) Family violence: Explanations and evidence-based clinical practice. American Counseling Association. Alexandria, VA.

Lee, C., Uppal, N., Erfani, P. and Peeler, K. (2020) 'COVID19 deaths in ICE detention demand medical action now.' The Hill. Available at: fromhttps://thehill.com/opinion/immigration/501261covid-19-deaths-in-ice-detention-demand-medical-actionnow (Accessed: 5 October 2020).

Mahapatra, N. and Rai, A. (2019) 'Every cloud has a silver lining but... Pathways to seeking formal-help and SouthAsian immigrant women survivors of intimate partner violence', Health Care for Women International, 40(11), pp. 1170-1196.

Mittal, S. and Singh, T. (2020) 'Gender-based violence during COVID-19 pandemic: a mini-review', Frontiers in Global Women's Health, 1(4), pp. 1-7.

Moreno, J.E. (2020) 'Trump refers to coronavirus as 'kung flu' during Tulsa rally.' The Hill. Available at: https://thehill.com/homenews/campaign/503756-trumprefers-to- coronavirus-as-kung-flu-during-tulsa-rally (Accessed: 4 October 2020).

Murugan, V. (2018) Intimate partner violence among South Asian women in the United States: Prevalence and helpseeking behaviors. Dissertation Abstracts International (Order No. 10606554) (Doctoral Dissertation, Washington University).

myPlan (2019) Available at: https://www.myplanapp.org/home (Accessed: 3 December 2020). 
Narea, N. (2020a) 'For immigrants without legal status, federal coronavirus relief is out of reach.' Vox. Available at:

https://www.vox.com/2020/5/5/21244630/undocumentedimmigrantscoronavirus-relief-cares-act (Accessed: 3 October 2020).

Narea, N. (2020b) 'The house's latest coronavirus relief bill gives stimulus payments to unauthorized immigrants.' Vox. Available at:

https://www.vox.com/2020/5/16/21260906/house-

stimulus-check-immigrants-heroes-act (Accessed: 4 October 2020).

Norman, R.E., Byambaa, M., De, R., Butchart, A., Scott, J., and Vos, T. (2012) 'The long-term health consequences of child physical abuse, emotional abuse, and neglect: A systematic review and meta-analysis', PLOS Medicine, 9(11), e1001349.

Perkins, N.H. and Barry, J.E. (2020) 'Should failure to protect laws include physical and emotional sibling violence?' Child \& Family Social Work, 25(1), pp. 206-209.

Perkins, N.H. and Grossman, S. (2020) 'Physical and emotional sibling violence: The missing piece in family violence policy', Advances in Social Work, 19(1), pp. 138156.

Perkins, N.H. and Shadik, J.A. (2018) 'A parent's perceptions of physical and emotional sibling Violence', Families in Society: The Journal of Contemporary Social Services, 99(1), pp. 78-86.

Perkins, N.H., Coles, D.C. and O'Connor, M.K. (2017) 'Sibling violence and policy: An examination of FoxHarding's child care value perspectives', Child \& Youth Services, 38(1), pp. 4-23.

Phelps, C., and Sperry, L.L. (2020) 'Children and the COVID19 pandemic', Psychological Trauma: Theory, Research, Practice, and Policy, S1, pp. S73-S75.

Price, S. (2019) 'Abused children four times more likely to develop mental illness.' Health Europa. Available at: https://www.healtheuropa.eu/abused-children-mentalillness-93690-2/93690/ (Accessed: 5 October 2020).

Radford, J. (2019) 'Key findings about U.S. immigrants.' Pew Research Center. Available at: https://www.pewresearch.org/fact-tank/2019/06/17/keyfindings-about-u-s-immigrants/ (Accessed: 5 October 2020).

Rapoza, K.A., Cook, K., Zaveri, T. and Malley-Morrison, K. (2010) 'Ethnic Perspectives on Sibling Abuse in the
United States', Journal of Family Issues, 31(6), pp. 808829.

Rai., A. (2020a) Perceptions, prevalence and help-seeking resources of domestic violence among South Asian immigrants in the United States. [Unpublished doctoral dissertation]. The University of Georgia.

Rai., A. (2020b) Domestic violence and Covid-19: How to support victims? Available at: https://sayfty.com/domesticviolence-and-covid-19-how-to-support- victims/

(Accessed: 30 November 2020).

Rai, A. and Choi, Y.J. (2018) 'Socio-cultural risk factors impacting domestic violence among South Asian immigrant women: A scoping review', Aggression and Violent Behavior, 38, pp. 76-85. Doi: https://doi.org/10.1016/j.avb.2017.12.001

Rochester Regional Health (2020) 'Pandemic vs epidemic: What's the difference?' Available at: https://www.rochesterregional.org/news/2020/03/pandemi c-vs-epidemic (Accessed: 5 October 2020).

Sabri, B., Simonet, M. and Campbell, J.C. (2018) 'Risk and protective factors of intimate partner violence among South Asian immigrant women and perceived need for services', Cultural Diversity and Ethnic Minority Psychology, 24(3), pp. 442-452.

Sandstrom, A. (2016) 'Most states allow religious exemptions from child abuse and neglect laws.' Pew Research Center. Available at: https://www.pewresearch.org/facttank/2016/08/12/most-states-allow-religious-exemptionsfrom-child-abuse-and-neglect-laws/ (Accessed: 5 October 2020).

Selvaratnam, T. (2020) 'Where can domestic violence victims turn during Covid-19?' The New York Times. Available at: https://www.nytimes.com/2020/03/23/opinion/coviddomestic-violence.html (Accessed: 5 October 2020).

Serrata, J.V. and Alvarado M.G.H. (2019) Understanding the impact of hurricane Harvey on family violence survivors in Texas and those who serve them'. Texas Council on Family Violence. Available at: https://tcfv.org/wpcontent/uploads/2019/08/Hurricane-Harvey-ReportFINAL-and-APPROVED-as-of-060619.pdf (Accessed: 5 October 2020).

Sexual Violence Research Initiative (2020) 'SVRI knowledge exchange: adjusting to COVID.' Available at: https://svri.org/sites/default/files/attachments/2020-0625/P2_Knowledge_Exchange_1.pdf (Accessed: 4 October 2020). 
Shirwadkar, S. (2004) 'Canadian domestic violence policy and Indian immigrant women', Violence Against Women, 10(8), pp. 860-879.

Snyder, R.L. (2020) 'Trapped at home: Coronavirus could be disastrous for domestic violence victims.' Los Angeles Times.

$$
\text { Available }
$$

https://www.latimes.com/entertainment-arts/story/202003-16/social-distancing-coronavirus-domestic-violence (Accessed: 4 October 2020).

Soglin, L.F., Ragavan, M., Immaneni, S., and Soglin, D.F. (2020) 'Assessing intimate partner violence in South Asian women using the Index of Spousal Abuse', Violence Against Women, 26(6-7), pp. 697-711.

Southall, A. (2020) 'Why a drop in domestic violence reports might not be a good sign.' The New York Times. Available at: https://www.nytimes.com/2020/04/17/nyregion/newyork-city-domestic-violence-coronavirus.html (Accessed: 4 October 2020).

Straus, M.A., Hamby, S.L., Boney-McCoy, S. and Sugarman, D.B. (1996) The Revised Conflict Tactics Scales (CTS2). Durham, NH: Family Research Laboratory, University of New Hampshire.

Tahirih Justice Center (2020) 'The impact of covid-19 on immigrant survivors of gender- based violence.' Available at: https://www.tahirih.org/wpcontent/uploads/2020/03/Impact-of-Social-Distancing-onImmigrant-Survivors-of-Gender-Based-Violence_FinalMarch-23-2020.pdf (Accessed: 5 October 2020).

Tolan, C. (2020) 'Some cities see jumps in domestic violence during the pandemic.' $C N N$. Available at: https://www.cnn.com/2020/04/04/us/domestic-violencecoronavirus-calls-cases-increase-invs/index.html (Accessed: 5 October 2020).

United Nations Women (2020a) Violence against women and girls: Datacollection during COVID-19. Available at: https://www.unwomen.org/-

/media/headquarters/attachments/sections/library/publicati ons/2020/vawg-data-collection- during-covid-19compressed.pdf?la=en\&vs=2339 (Accessed: 4 October 2020).

United Nations Women (2020b) COVID-19 and ending violence against women and girls. Available at: https://www.unwomen.org//media/headquarters/attachmen ts/sections/library/publications/2020/issue-brief-covid-19and-ending-violence-against-women-and-girlsen.pdf?la=en\&vs=5006 (Accessed: 5 October 2020).
U.S. Department of Justice (2015) Intimate partner violence, 1993-2010.

Available

at:

https://www.bjs.gov/content/pub/pdf/ipv9310.pdf

(Accessed: 7 October 2020).

U.S. Immigration and Customs Enforcement (2020) ICE Guidance on COVID-19: Overview and FAQs. Available at: https://www.ice.gov/coronavirus (Accessed: 5 October 2020).

USCIS (2016) Battered spouse, children and parents. Available at: https://www.uscis.gov/humanitarian/battered-spousechildren-and-parents (Accessed: 4 October 2020).

USCIS (2017) Employment authorization for certain $\mathrm{H}-4$ dependent spouses. Available at: https://www.uscis.gov/working-united-states/temporaryworkers/faqs-employment-authorization-certain-h-4dependent-spouses (Accessed: 5 October 2020).

U.S. Embassy and Consulates in India (2020) COVID-19 information. Available at: https://in.usembassy.gov/covid19-information/ (Accessed: 5 October 2020).

Viveiros, N. and Bonomi, A.E. (2020) 'Novel coronavirus (COVID-19): Violence, reproductive rights and related health risks for women, opportunities for practice and innovation', Journal of Family Violence, 1, pp. 1-5. Doi: 10.1007/s10896-020-00169-x

Voolma, H. (2018) 'I must be silent because of residency: Barriers to escaping domestic violence in the context of insecure immigration status in England and Sweden', Violence Against Women, 24(15), pp. 1830-1850. Doi: $10.1177 / 1077801218755974$

World Health Organization (2020) WHO Director-General's opening remarks at the media briefing on COVID-19. Available at: https://www.who.int/dg/speeches/detail/whodirector-general-s-opening-remarks-at-the-media-briefingon-covid-19---3-march-2020 (Accessed: 5 October 2020).

Wiehe, V.R. (1997) Sibling abuse: Hidden physical, emotional, and sexual trauma. $2^{\text {nd }}$ edn. Thousand Oaks, CA: Sage.

Winters, K.E. (2019) Physical and emotional sibling violence and child welfare: A critical realist exploratory study (Unpublished doctoral dissertation). Retrieved from ProQuest Dissertations and Theses Database (No. 13806345).

Yang, Y. and Bloomberg (2020) 'Trump set to announce new restrictions on $\mathrm{H}-1 \mathrm{~B}$ visa program for foreign workers.' The Fortune. Available at: 
https://fortune.com/2020/06/21/trump-h1b-visa-programrestrictions/ (Accessed: 5 October 2020).

Yoshihama, M., Bybee, D., Dabby, C. and Blazevski, J. (2011) Life course Experiences of Intimate Partner Violence and Help-Seeking among Filipina, Indian, and Pakistani Women: Implications for Justice System Responses. Available at: https://www.ncjrs.gov/pdffiles 1/nij/grants/236174.pdf (Accessed: 5 October 2020).

Yoshioka, M.R., Gilbert, L., El-Bassel, N. and Baig-Amin, M. (2003) 'Social support and disclosure of abuse: Comparing South Asian, African American, and Hispanic battered women', Journal of Family Violence, 18(3), pp. 171-180. Doi: https://doi.org/10.1023/A:1023568505682 